\title{
PERAN ORANG TUA SEBAGAI PENDIDIK ANAK DALAM KELUARGA
}

\author{
Adrian dan Muhammad Irfan Syaifuddin \\ Pascasarjana, STAIN Syaikh Abdurrahman Siddik Bangka Belitung, Bangka \\ Fakultas Tarbiyah, IAIN Surakarta, Solo \\ adrian.rusman.gumay@gmail.com
}

\begin{abstract}
This article discusses the role of parents as child educators in the household. Many Muslim scholars quoted quran verses and hadith as the basis for the importance of children's education in the family. The family is the smallest instrument in the community and is the basic platform as well as a place for early education for every child. The role of parents is very important in children's education. Parents who are able to position themselves as protectors, protectors, and educators of children will certainly be coherent in the hope that they will get good future generation candidates, because the nature of children is in need of love and attention from their parents. Will of Lukman al-Hakim in Q.S. Luqman verses 13-19 is a manifestation of the importance of children's education by parents in the family. Education in the family is not only limited to religious education, but also provides moral, personality and social education. Parents should be able to carry out holistic education to children in the family so that they can realize the goal of education, namely to make a complete person balanced between emotions, intellectuals, and spirituality
\end{abstract}

Keywords: Education, Child, Parents, Family

Abstrak

Artikel ini membahas tentang peran orang tua sebagai pendidik anak dalam rumah tangga. Para sarjana Muslim banyak menukil ayat-ayat qur'an dan hadis sebagai dasar petingnya pendidikananak dalam keluarga. Keluarga sebagai instrumen terkecil dalam masyarakat dan sebagai peletak dasar sekaligus tempat pendidikan awal bagi setiap anak. Peran orang tua sangatlah penting dalam pendidikan anak. Orang tua yang mampu memposisikan diri sebagai pelindung, pengayom, dan pendidik anak tentunya akan koheren dengan harapan agar mendapat calon generasi penerus yang baik, karena sifat dasar anak adalah membutuhkan kasih sayang dan rhatian dari orang tuanya. Wasiat Lukman al-Hakim dalam Q.S. Luqman ayat 13-19 merupakan manifestasi dari pentingnya pendidikan anak oleh orang tua dalam keluarga. Pendidikan dalam keluarga bukan hanya dibatasi dalam pendidikan agama saja, namun juga memberikan pendidikan akhlaq, kepribadian, dan sosial. Orang tua sepantasnya mampu melaksanakan pendidikan holistik kepada anak dalam keluarga sehingga mampu mewujudkan tujuan pendidikan yaitu menjadikan insan paripurna yang seimbang antara emosi, intelektual, dan spiritual.

Kata kunci: Pendidikan, anak, orang tua, keluarga 


\section{| ADRIAN, IRFAN | Peran Orang Tua sebagai Pendidik Anak}

\section{A. PENDAHULUAN}

Pendidikan merupakan sarana utama bagi manusia untuk berkembang dan menunjukkan eksistensinya sebagai manusia ${ }^{1}$. Keberadaan manusia di bumi ini bisa dilihat dari budaya yang tumbuh di tengah-tengah masyarakat. Sejak zaman pra sejarah hingga post modern mempunyai kebudayaan yang hidup dan dijunjung tinggi oleh anggota masyarakat. Masyarakat dalam mempertahankan kebudayaannya tentu tidak lepas dari pendidikan, yang dilakukan dari generasi ke generasi.

Masyarakat sebagai pembentuk budaya, merupakan wadah besar dari institusi-institusi kecil pembentuk masyarakat, yaitu keluarga. Keluarga terbentuk dari ikatan perkawinan antara pasangan suami-istri untuk hidup dalam sebuah rumah tangga ${ }^{2}$, kemudian menurunkan anak dan berkembang menjadi keluarga yang lebih besar lagi. Keluarga mempunyai kontribusi penting dalam melestarikan budaya yang secara turun menurun diajarkan oleh orang tua kepada anak-anaknya. Semakin kuat pendidikan dalam keluarga maka semakin kuat pula keberlangsungan budaya dalam suatu masyarakat.

Tujuan pendidikan dalam keluarga adalah agar anak berkembang dengan baik, meliputi seluruh aspek perkembangan anak, yaitu akal, jasmani dan rohani. ${ }^{3}$ Tujuan lain ialah membantu sekolah atau lembaga pendidikan lain dalam mengembangkan pribadi anak didiknya.

Pendidik dalam keluarga dan yang paling bertanggung jawab terhadap pendidikan anak dalam rumah tangga adalahorang tua. ${ }^{4}$ Orang tua mempunyai

\footnotetext{
${ }^{1}$ Mengutip pernyataan Habermas tentang positivisme, bahwa ilmu pengetahuan dibagi ke dalam tiga kategori. Pertama, instrumental knowledge, ilmu pengetahuan dijadikan alat untuk mengontrol, dan eksploitasi terhadap objeknya. Kedua, hermeneuticknowledge, ilmu pengetahuan hanya digunakan untuk memahami suatu objek. Ketiga, emancipatoryknowledge, ilmu pengetahuan dijadikan catalyst untuk membebaskan potensi manusia. Lihat MansourFakih,"ideologi dalam pendidikan”, pengantar dalam William F. O'neil, Ideologi-idelogi Pendidikan. terj. Omi Intan Naomi, Yogyakarta: Pustaka Pelajar, 2001, hlm. xv-xvi.

${ }^{2}$ Mufatihatut Taubah, "Pendidikan Anak dan Keluarga Perspektif Islam". Jurnal Pendidikan Agama Islam, Vol. 03, No. 1 Mei 2015, hlm. 112.

${ }^{3}$ Menyiapkan anak untuk menjadi pribadi mulia merupakan salah satu tugas utama orang tua dalam kehidupan berkeluarga. Islam memberikan rambu-rambu kepada setiap orang tua dalam menyiapkan putra-putrinya. Menukil beberapa ayat dalam al-Qur'an, yaitu Q.S. At-Tahrim(66): 6

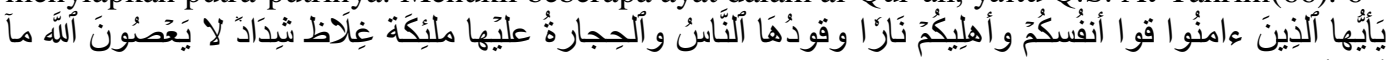

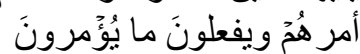

dan juga dalam Q.S. Ash-Shu'ara (26): 214

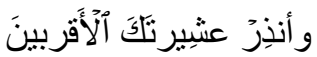

Ayat-ayat di atas mengindikasikan peran orang tua dalam melaksanakan pendidikan anak dalam keluarga dengan menjaga mereka dan memperingatkan mereka untuk selalu melaksanakan perintah-perintah Allah dan Rosulullah dan menjauhi larangan-larangan Allah dan rosul-Nya. Sekaligus mempertegas tujuan pendidikan anak dalam keluarga, yaitu: Memelihara keluarga dari api neraka, beribadah kepada Allah SWT, Membentuk Akhlak Mulia, dan membentuk anak agar kuat secara individu, sosial, dan sosial. Lihat dalam Helmawati, Pendidikan Keluarga: Teoritis dan Praktis, Bandung: Remaja Rosdakarya, 2104, hlm. 50-51.

${ }^{4}$ Orang tua merupakan pendidik bagi anak-anak mereka dalam keluarga dan karena orang tua adalah orang yang pertama kali mengajarkan sesuatu bagi anak. Sekalipun keluarga adalah tempat
} 


\section{| ADRIAN, IRFAN | Peran Orang Tua sebagai Pendidik Anak}

peran sentral dalam pendidikan anak. Namun yang terjadi, banyak orang tua yang hanya melimpahkan pendidikan anak kepada guru di sekolah. Orang tua beralasan karena bekerja mencari nafkah untuk kebutuhan keluarga. Hal ini mungkin karena orang tua tidak memahami hakikat pendidikan anak dalam keluarga dan pentingnya peran orang tua dalam membentuk pribadi anak dalam keluarga.

Posisi anak didik dalam keluargaadalah anak. Agar anak bisa berkembang secara optimal dan menjadi anak yang terdidik dalam pendidikan yang baik sejak masa dininya, maka orang tua sebagai yang paling bertanggung jawab dalam pembentukan anak sejak masa awal, harus memperhatikan pola pendidikan sehingga akan memperoleh hasil yang maksimal, anak mampu berkreasi, mandiri dan memberikan kontribusi nyata kelak di masa yang akan datang.

Memperhatikan latar belakang di atas, dapat dikatakan bahwa peran orang tua sangat diperlukan sebagai pendidik anak dalam keluarga. Revitalisasi peran orang tua sebagai pendidik anak dapat diwujudkan jika orang tua memahami hakikat pendidikan anak dalam keluarga. Tulisan ini memberikan gambaran bagaimana orang tua mengambil peran sentral dalam pendidikan anaknya dengan menjadikan keluarga sebagai wadah utama pendidikan anak.

\section{B. PENDIDIKAN ANAK DALAM KELUARGA}

Pendidikan dalam beberapa definisi yang dikemukakan oleh beberapa ahli pendidikan disimpulkan sebagai sebuah usaha sadar yang diselenggarakan berdasarkan nilai tertentu untuk membimbing dan membina manusia yang dididik agar ia dapat mengembangkan dan menyalurkan segenap potensi dari jasmani,

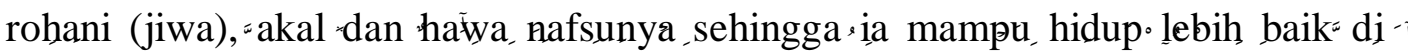
masa yang akan datang. ${ }^{5}$

pendidikan infomal namun keluarga merupakan tempat pendidikan tertua sekaligus memberikan berbagai pengaruh atau nilai kepada anak. Lihat dalam ibid., hlm. 50.

${ }^{5}$ Soegarda Poerbakawatja, dkk., Ensiklopedi Pendidikan, (Jakarta: Gunung Jati, 1981), hlm. 257 258. 
peran sentral dalam pendidikan anak. Namun yang terjadi, banyak orang tua yang hanya melimpahkan pendidikan anak kepada guru di sekolah. Orang tua beralasan karena bekerja mencari nafkah untuk kebutuhan keluarga. Hal ini mungkin karena orang tua tidak memahami hakikat pendidikan anak dalam keluarga dan pentingnya peran orang tua dalam membentuk pribadi anak dalam keluarga.

Posisi anak didik dalam keluargaadalah anak. Agar anak bisa berkembang secara optimal dan menjadi anak yang terdidik dalam pendidikan yang baik sejak masa dininya, maka orang tua sebagai yang paling bertanggung jawab dalam pembentukan anak sejak masa awal, harus memperhatikan pola pendidikan sehingga akan memperoleh hasil yang maksimal, anak mampu berkreasi, mandiri dan memberikan kontribusi nyata kelak di masa yang akan datang.

Memperhatikan latar belakang di atas, dapat dikatakan bahwa peran orang tua sangat diperlukan sebagai pendidik anak dalam keluarga. Revitalisasi peran orang tua sebagai pendidik anak dapat diwujudkan jika orang tua memahami hakikat pendidikan anak dalam keluarga. Tulisan ini memberikan gambaran bagaimana orang tua mengambil peran sentral dalam pendidikan anaknya dengan menjadikan keluarga sebagai wadah utama pendidikan anak.

\section{B. PENDIDIKAN ANAK DALAM KELUARGA}

Pendidikan dalam beberapa definisi yang dikemukakan oleh beberapa ahli pendidikan disimpulkan sebagai sebuah usaha sadar yang diselenggarakan berdasarkan nilai tertentu untuk membimbing dan membina manusia yang dididik agar ia dapat mengembangkan dan menyalurkan segenap potensi dari jasmani, rohani (jiwa), akal dan hawa nafsunya sehingga ia mampu hidup lebih baik di masa yang akan datang. ${ }^{5}$

pendidikan infomal namun keluarga merupakan tempat pendidikan tertua sekaligus memberikan berbagai pengaruh atau nilai kepada anak. Lihat dalam ibid., hlm. 50.

${ }^{5}$ Soegarda Poerbakawatja, dkk., Ensiklopedi Pendidikan, (Jakarta: Gunung Jati, 1981), hlm. 257258. 
Keluarga dalam beberapa difinisi juga di simpulkan sebagai kelompok dua orang atau lebih yang ada hubungan darah, perkawinan, dan adobsi yang hidup bersama. Sehingga keluarga bisa terbentuk oleh dua bersaudara atau lebih yang hidup bersama, seorang bapak atau ibu yang hidup bersama seorang anak atau beberapa anak, dua orang dewasa yang menikah dan hidup bersama sekalipun tanpa anak, atau seorang dewasa yang hidup bersama dengan anak adopsi. ${ }^{6}$ Sekelompok manusia yang hanya terdiri dari ibu, bapak, dan anak disebut keluarga inti (nuclearfamily). Sedangkan keluarga luas (extendedfamily) mencakup semua orang berketurunan dari kakek-nenek yang sama, termasuk keturunan masing-masing isteri dan suami. ${ }^{7}$ Selain kedua model keluarga tersebut, masih terdapat dua model keluarga yaitu keluarga pangkal (stemfamily) dan keluarga gabungan (jointfamily). ${ }^{8}$ Keluarga pangkal adalah keluarga yang menggunakan sistem pewarisan kekayaan pada satu anak yang paling tua. Anak pertama bertanggung jawab terhadap adik-adaiknya perempuan dan laki-laki sampai ia menikah. Sedang keluarga gabungan adalah keluarga yang terdiri banyak keluarga dari satu garis keturunan (bisa patrilineal atau matrilineal) yang hidup bersama dengan pasangan mereka dalam satu rumah dan di bawah kekuasan salah satu anggota keluarga. ${ }^{9}$ Keluarga gabungan adalah pengembangan dari keluarga inti, dalam banyak kasus adalah ketika seorang yang telah menikah dan tidak ingin meningalkan orang tuanya, namun membawa pasangannya untuk tinggal bersama dengan orang tua dalam satu rumah. ${ }^{10}$

\footnotetext{
${ }^{6}$ Definisi keluarga menurut U.S. BureauoftheCencus, lihat dalam Roberta M. Berns, Child, Family, School, Community: SocializationandSupport, (Stamfort: CengageLearning, 2016), hlm. 84.

${ }^{7}$ A.G. Pringgodigdo, dkk. Ensiklopedi Umum, (Jakarta: Yayasan Dana Buku Franklin, 1973), hlm. 544.

${ }^{8}$ H. Mahmud, dkk., Pendidikan Agama Islam dalam Keluraga: Sebuah Panduan Lengkap bagi Guru, Orang Tua, dan Calon, (Jakarta: Akademia, 2013), hlm. 129.

9 Juga bisa diartikan sebagai sebuah sistem keluarga dimana anak pertama dan pasangannya tinggal di rumah orang tua, anak mereka tumbuh bersama kakek maupun nenek dalam keluarga, sedang anak kedua dan selanjutkan akan meninggalkan rumah jika telah menikah. Lihat dalam wiktionary di laman https://en.wiktionary.org/wiki/stem_family.

${ }_{10}$ Keluarga gabungan (jointfamily) berbeda dengan keluarga luas (extendedfamily), dalam keluarga gabungan semua anggota keluarga mengerjakan semua tugas keluarga sesuai dengan fungsi anggota dalam keluarga tersebut, mulai dari mencari makan (nafkah), berjualan, menyiapkan makanan, ataupun mengasuh anak. Hubungan antara anggota kelurga sangat melekat (cohesive), dalam banyak keluarga bahkan setiap perempuan dewasa dipanggil "ibu" oleh anakanak. Lihat dalam InsiclopediaBritannica di laman www.britannica.com/topic/joint-family.
} 
Kedua pengertian menerangkan bahwa pendidikan anak dalam keluarga adalah usaha sadar dari orang tua dalam menyelenggarakan pendidikan berdasarkan nilai-nilai agama dan akhlak mulia untuk membimbing anak agar dapat dan menyalurkan segenap potensi dari jasmani, rohani (jiwa), akal dan hawa nafsunya sehingga ia mampu hidup lebih baik di masa yang akan datang.

Keluarga merupakan salah satu dari tiga pilar pendidikan selain sekolah dan masyarakat. Keluarga menjadi titik tolak perkembangan anak. Peran orang tua sangat penting dalam mendidik anak agar menjadi cerdas, sehat dan mempunyai kepekaan sosial yang baik. Prestasi yang dicapai siswa dalam pendidikannya bukan hanya disebabkan keberhasilan sekolah atau madrasah sebagai institusi pendidikan formal, tetapi juga karena peran keluarga yang serius mendidik anak untuk dalam kehidupan sehari-hari. ${ }^{11}$

Pendidikan anak dalam keluarga bertujuan mendidik dan menyiapkan anak menjadi manusia dewasa yang memiliki kapasitas utama (berimbang antara IQ dan EQ) dan bertanggung jawab baik secara moral, agama, maupun sosial kemasyarakatan. Tujuan pendidikan tersebut dapat tercapai bila orang tua memahami akan peran mereka sebagai pendidik utama anak dalam keluarga. Perbuatan orang tua akan menjadi acuan bagi anak sebab sifat dasar anak adalah meniru kepada apa yang dilihat. Maka, orang tua hendaknya memberikan bimbingan, asuhan, dan suri tauladan yang baik bagi anak-anak dalam keluarga. ${ }^{12}$ Seperti dalam filosofi pendidikan Ki Hajar Dewantoro; Ing ngarso sung tulodho, ing madya mangun karso, tutwurihandayani.

\section{KELUARGA SEBAGAI WADAH UTAMA PENDIDIKAN}

Keluarga terbentuk dari perkawinan yang sah dan diakui. Sah berarti terpenuhinya syarat dan rukun nikah, serta diakui oleh negara sebagai pernikahan yang tercatat sesuai dengan tata aturan dan perundang-undangan. Jika keluarga yang terbentuk sah dan diakui oleh negara maka menjadikan keluarga yang

\footnotetext{
${ }^{11}$ Helmawati, Pendidikan ..., hlm. 49.

${ }^{12}$ H. Mahmud, dkk., Pendidikan Agama ..., hlm. 155.
} 


\section{| ADRIAN, IRFAN | Peran Orang Tua sebagai Pendidik Anak}

tentram. Keluarga sebagai wadah pendidikan anak seharusnya mendapatkan perhatian utama dari setiap orang tua. ${ }^{13}$ Orang tua bertugas untuk mewujudkan kehidupan rumah tangga yang sakinah, mawaddah, dan rahmah di antara anggota keluarga; suami, istri, dan anak. ${ }^{14}$ Jika orang tua mampu mewujudkan rasa cinta kasih dan kedamaian dalam keluarga, maka orang tua pun mampu mewujudkan keturunan yang tangguh, tumbuh dan berkembang menjadi anak yang berkualitas. ${ }^{15}$

${ }^{13}$ Zakiyah Daradjat, Pendidikan Islam dalam Keluarga dan Sekolah, (Bandung: Remaja Rosdakarya, 1994), hlm. 41-44.

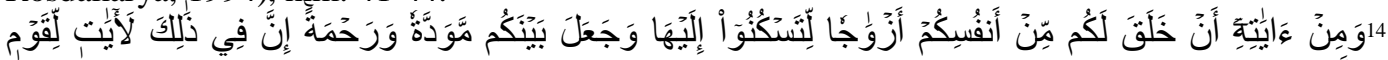

${ }^{15}$ H. Mahmud, dkk., Pendidikan Agama ..., hlm. 132. 


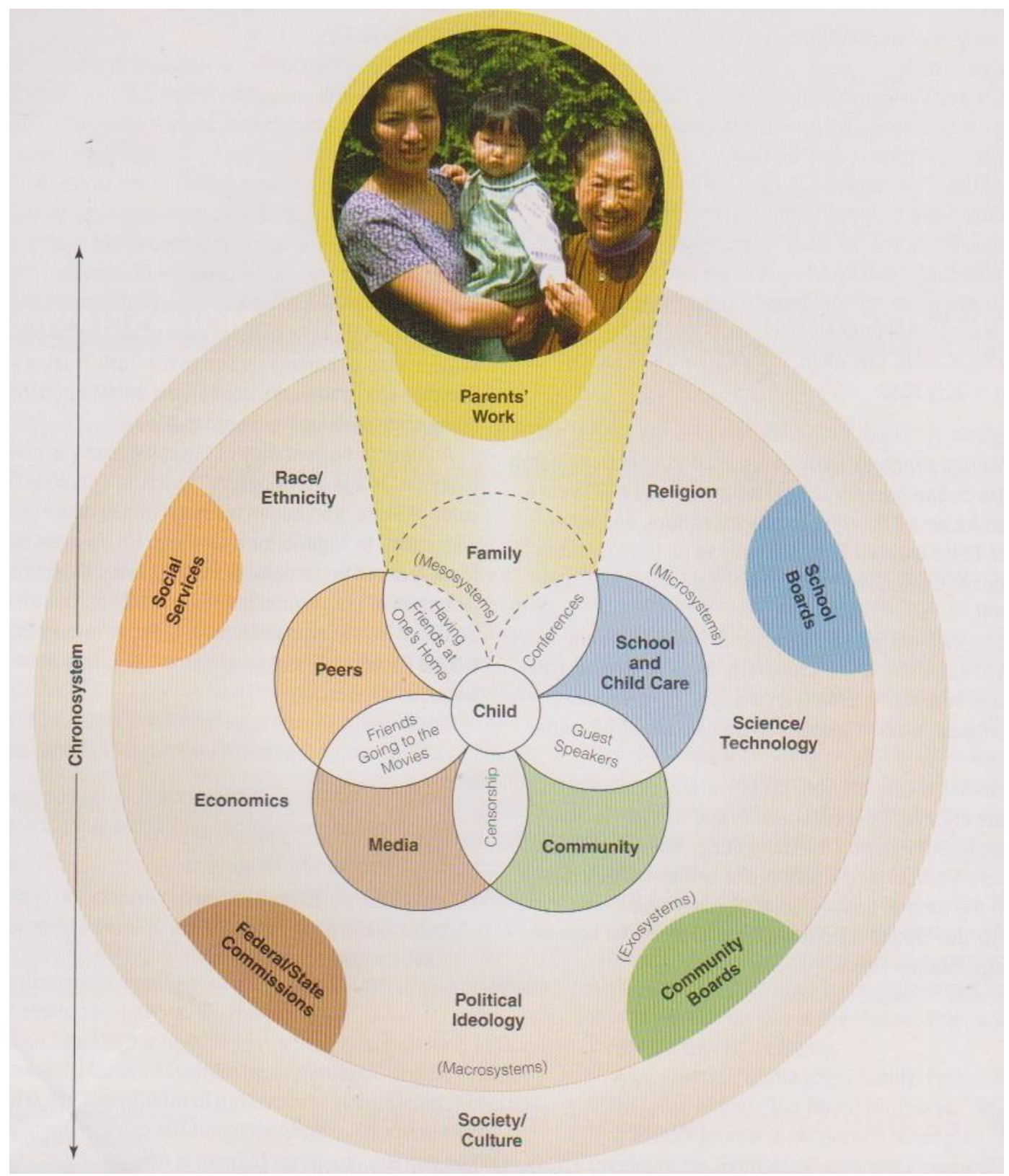

Gambar 1. Keluarga sebagai institusi pertama yang memberikan pengaruh dalam perkembangan anak

Keluarga adalah wadah pertama dan utama bagi pendidikan anak. Keluarga sebagai lingkungan pendidikan yang sangat berpengaruh dalam membentuk pola kepribadian anak. Anak mempelajari nilai-nilai keyakinan (agama), akhlak budi pekerti, komunikasi dan intertaksi sosial, serta ketrampilan hidup dari keluarga 
dan orang tua. ${ }^{16}$ Orang tua bertanggung jawab melaksanakan tugas memelihara, mengasuh, dan mendidik anak lahir dan batin sampai anak menjadi dewasa. ${ }^{17}$

Orang tua selayaknya mengetahui beberapa aspek pengetahuan dasar tentang pertumbuhan dan perkembangan anak. Tumbuh kembang anak membutuhkan dua jenis makanan; makanan lahir dan batin. Makanan lahir berupa pemenuhan nutrisi dan gizi yang baik dan seimbang untuk anak sesuai dengan jenjang umurnya, sedang makanan batin berupa kasih sayang, perhatian, pendidikan, dan pembinaan kejiwaan yang diberikan orang tua kepada anak dalam kehidupan sehari-hari. ${ }^{18}$

Usahamemehuni kebutuhan batinanak dalam keluarga adalah dengan menciptakan rasa saling pengertian, saling menghargai, saling mempercayai, dan saling menyanyangi di antara seluruh anggota keluarga. Sehingga suasana keluarga akan menjadi cerah ceria. Suasana kelurga yang cerah ceria tersebut menjadi tanah yang subur bagi penyemaian tunas-tunas muda yang lahir dalam keluarga itu.

Kebutuhan jasmani anak juga menjadi kewajiban orang tua yang harus dipenuhi. Anak yang masih bayi, Allah menyediakan ASI pada ibu yang melahirkan anak. ${ }^{19}$ Untuk anak yang telah bertambah dewasa, maka orang tua wajib memenuhi kebutuhan jasmaninya dengan menyediakan makanan bergizi yang menjadi nutrisi terbaik untuk anaknya. Tersedianya makanan yang bergizi yang mengandung nutrisi yang baik dan berimbang sangat dibutuhkan bagi anak dalam masa tumbuh kembangnya.

Tanggung jawab orang tua pertumbuhan dan perkembangan anak, tidak terjadi secara instan tetapi dengan berangsur-angsur melalui pengalaman yang dilalui anak-anak. Orang tua yang dalam perawatan, pemeliharaan dan

\footnotetext{
${ }^{16}$ Helmawati, Pendidikan ..., hlm. 49.

${ }^{17}$ H. Mahmud, dkk., Pendidikan Agama ..., hlm. 132..

${ }^{18}$ Tumbuh kembang anak akan tergangu, jika orang tua tidak mampu memberikan dua jenis kebutuhan anak (jasmani dan rohani). Anak yang tumbuh dalam keluarga yang mengalami disfungsi keluarga mempunyai resiko terganggu tumbuh kembangnya dari pada anak yang tumbuh dalam keluarga yang harmonis, utuh, dan memperhatikan kebutuhan nutrisi anak. Lihat dalam ibid., hlm. 133.

${ }^{19}$ Para ibu hendaknya menyusui anak-anaknya selama dua tahun penuh, yaitu bagi yang ingin menyempurnakan penyusuan. Dan kewajiban ayah memberi makan dan pakaian kepada ibu dengan cara ma'ruf. (Q.S. al-Baqarah (2): 233)
} 
pendidikan, serta menyusui diserahkan kepada orang lain, bahkan pada masa awal pertumbuhan anak, maka orang tua hanya melihat anak sebagai objek yang harus diurus tanpa ada ikatan batin yang terbangun antara orang tua dan anak. ${ }^{20}$

Berbeda dengan orang tua yang dalam perawatan, pemeliharaan dan pendidikan, serta menyusui dilakukan sendiri masa awal pertumbuhan anak, maka orang tua telah memenuhi kebutuhan jasmani anak dan sekaligus pula kebutuhan akan kasih sayang dan rasa aman. Anak yang kebutuhan jasmani dan rohani dipenuhi oleh orang tua, akan akan tumbuh menjadi anak yang kuat secara fisik dan rohani sehingga mantap menatap masa depannya. ${ }^{21}$

Kewajiban mengasuh dan memelihara anak merupakan tanggung orang tua untuk meningkatkan kualitas pertumbuhan anak, mencegah penelataran, dan perlakuan yang tidak adil bagi anak. Karena orang tua adalah pendidik utama dan pertama bagi anak-anak mereka, dan keluarga menjadi institusi terkuat dalam masyarakat, sekaligus dengan keluarga seseorang memperoleh kemanusiannya. ${ }^{22}$

\section{CAKUPAN PENDIDIKAN ANAK DALAM RUMAH TANGGA}

Setiap bentuk pendidikan tentu mempunyai kurikulum, pendidikan dalam keluarga juga mempunyai kurikulum, tetapi berbeda dengan kurikulum pendidikan di lembaga pendidikan formal. Kurikulum pendidikan dalam keluarga secara umum mencakuppendidikan jasmani dan ketrampilan, akal, dan kejiwaan anak. $^{23}$

Orang tua harus wajib memperhatikan pendidikan jasmani anaknya. Pendidikan jasmani diberikan kepda anak sejak kecil yang disesuaikan dengan perkembangan dan petumbuhan anak. Orang tua ialah menanamkan dan

20 Bisa juga disebut dengan berkurangnya peran orang tua ke anak sebagai akibat dari dilimpahkannya fungsi orang tua ke orang lain, seperti fungsi ibu dalam menyusui, merawat dan memelihara si anak pada masa pertumbuhan anak. Sehingga kecenderungan anak kepada ibunya berkurang, kemudian mempunyai kepada orang lain yang selama ini memberikan banyak waktu untuk merawat dan memeliharanya.

${ }^{21}$ Zakiyah Daradjat, Pendidikan Islam ..., hlm. 52.

${ }^{22}$ H. Mahmud, dkk., Pendidikan Agama ..., hlm. 135.

${ }^{23}$ Ahmad Tafsir, Ilmu Pendidikan dalam Perspektif Islam, (Bandung: Remaja Rosdakarya, 1991), hlm. 156. 
membiasakan hidup sehat kepada anak dalam kehidupan sehari-hari, memberi contoh hidup sehat, makanan yang bergizi, makan dan minum yang teratur, serta istirahat cukup. ${ }^{24}$

Anak harus dibimbing oleh orang tua agar memiliki akal yang pandai. Orang tuamenyerahkan anak ke lembaga pendidikan formal merupakan usaha dalam rangka mengasah kemampuan akal anak, karena lembaga pendidikan formal adalah lembaga yang sesuai untuk mengembangkan akal anak dengan membuat kurikulum pendidikan yang berjenjang sesuai dengan fase perkembangan anak. Akan tetapi, bukan berarti bahwa di rumah orang tua bebas sama sekali dari kewajiban melaksanakan pendidikan akal. Menyertakan anak dalam menyelesaikan masalah bersama anggota keluarga dan mendampingi anak menyelesaikan pekerjaan rumah. Orang tua juga perlu menanamkan pada anak betapa pentingnya usaha untuk memiliki akal yang pandai. ${ }^{25}$

Pendidikan rohani atau psikis bagi anak dalam keluarga juga mendapatkan tempat yang penting. Karena tujuan pendidikan psikis adalah pembinaan mental dan kepribadian anak, sehingga jika anak tumbuh jadi dewasa dapat mengoptimalkan peran sebagai khalifatullah filard. Pendidikan rohani juga bisa diartikan sebagai pendidikan agama dalam keluarga, yaitu dengan menanamkan nilai dalam arti pandangan hidup, yang kelak mewarnai perkembangan jasmani dan akalnya. ${ }^{26}$

Pendidikan agama penting untuk dibiasakan kepada anak dalam keluarga. Jika anak sudah memiliki basis nilai agama yang dibawa dari rumah, secara sederhana anak dapat memberikan nilai terhadap teori-teori yang diajarkan di sekolah. Pendidikan agama di rumah berfungsi menanamkan nilai pengetahuan pada anak. Kemampuan "menyaring" dan "memberi nilai" teori pengetahuan seperti ini amat penting artinya bagi anak itu dalam perkembangan pengetahuannya di kemudian hari.

\footnotetext{
${ }^{24}$ Ibid.

${ }^{25}$ Ibid., hlm. 157.

${ }^{26}$ Ibid.
} 


\section{| ADRIAN, IRFAN | Peran Orang Tua sebagai Pendidik Anak}

Sebagai contoh pelaksanaan dari pendidikan agama dalam keluarga adalah menghargai guru dan ilmu pengetahuan yang diberikan. Pendidikan di sekolah tidak akan berhasil secara maksimal bila murid tidak tidak menghormati guru dan pengetahuannya. Sehingga bisa dikatakan bahwa salah satu kunci keberhasilan pendidikan di sekolah ialah ada atau tidaknya penghargaan dari murid terhadap guru dan terhadap pengetahuan yang diajarkannya. Untuk menanamkan sikap yang demikianmaka pendidikan agama (Islam) merupakan kunci utama. Pendidikan agama Islam dilakukan di rumah sebagai lembaga pertama dan utama. ${ }^{27}$

\section{E. PERAN ORANG TUA SEBAGAI PENDIDIK ANAK DALAM KELUARGA}

Pendidikan anak adalah tanggung jawab orang tua. Peran orang tua dalam pendidikan anak sangatlah penting, karena anak memperoleh kesinambungan nilai-nilai kebaikan yang diajarkan di sekolah melalui orang tua. Keterlibatan orang tua dan keluarga dalam pendidikan anak menjadi mutlak menjadi penyempurna dari nilai-nilai yang diajarkan di sekolah, sebab pendidikan anak (khususnya pendidikan akhlak) harus mengandung unsur afeksi, perasaan, sentuhan nurani, dan dipraktekkan dalam kehidupan sehari-hari. ${ }^{28}$

Peran orang tua sebagai pendidik anak dalam keluarga tercermin pada profil Luqman al-hakim sebagaimana yang disebutkan dalam Q.S. Luqman (31): 13-19.

\footnotetext{
${ }^{27}$ Pendidikan agama Islam itu dilakukan di rumah sebagai lembaga pertama dan utama mengandung arti bahwa Pendidikan agama dalam rumah tangga berlanjut pada pendidikan agama di sekolah, dimana posisi pendidikan agama di sekolah itu sama atau hampir sama dengan pendidikan agama di rumah tangga. Sehingga pendidikan agama di sekolah juga menjadi kunci pendidikan pada umumnya. Akan tetapi di pihak lain, pendidikan agama di sekolah itu ridak dapat berhasil bila pendidikan agama di rumah gagal. Jadi, tetap saja pendidikan agama di rumah meruapakan kunci utama pendidikan agama di sekolah dan pendidikan di sekolah secara keseluruhan. Ahmad Tafsir, Ilmu Pendidikan ..., hlm. 158.

${ }^{28}$ Masturin, "Pendidikan Karakter pada Materi PAI dalam Pembentukan Manusia Berkualitas", Jurnal Pendidikan Dasar Islam Al-Bidayah, Vol. 7 Nomor 1, Tahun 2015., hlm. 57.
} 
Allah mengawalinya dengan menggambarkan Luqman $^{29}$ sebagai seorang yang dikaruniai hikmah dan kebijaksanaan:

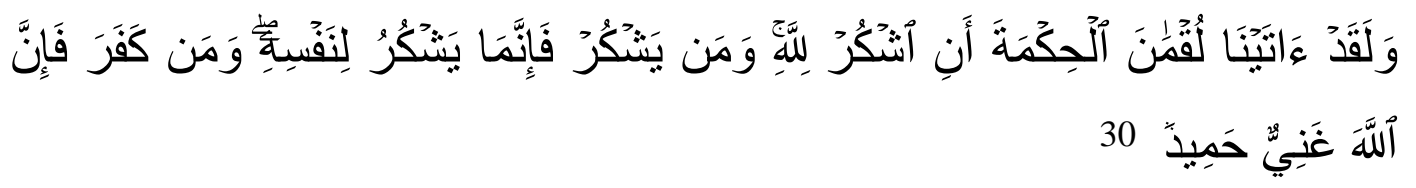

Islam sangat memperhatikan pendidikan anak dalam rumah tangga. Peran orang tua sebagai pendidik anak yang utama dalam keluarga. Orang tua menjalankan tugas untuk mendidik anak, memperhatikan pertumbuhan, dan perkembangan anak. Untuk mewujudkan anak yang terdidik dan menjadi manusia yang beriman, bertakwa dan berakhlak terpuji di kemudian hari, maka orang tua untuk memperhatikan akan peran orang tua seperti Luqman al-hakim sebagaimana yang dijelaskan dalam Q.S. Luqman (31): 13-19. Peran-peran tersebut adalah:

1. Pembinaiman dan tauhid

Luqman memulai nasihat kepada anaknya ${ }^{31}$ untuk menghidari perbuatan syirik atau menyekutukan Allah. Nasihat untuk menghindari perbuatan syirik juga mengandung pengajaran tentang wujud dan keesaan Allah SWT.

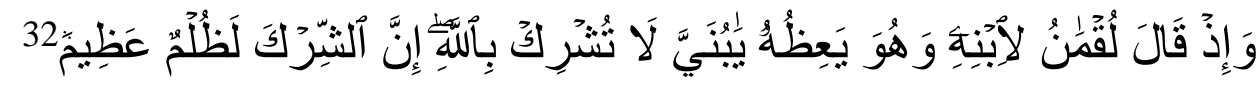

Penyebutan kata (يعظه) memberi gambaran tentang cara Luqman berkata kepada anaknya, yakni dengan penuh kasih sayang selayaknya orang tua mengucapkan kata-kata dengan lembut bukan dengan cara membentak.

\footnotetext{
29 Nama lengkapnya adalah Luqman bin 'Anqa' bin Sadun, terjadi perdebatan antara mufassirinapakah Luqman seorang nabi ataukah hanya seorang hamba yang sholeh. Pendapat yang diambil oleh jumhur adalah bahwa Luqman bukan sorang nabi, tetapi adalah seorang hamba sholeh yang yang diberi himah dari Allah SWT. Ibnu Abbas menggambarkan Luqman sebagai orang kulit hitam dari Sudan dan berprofesi sebagai tukang kayu. Mujahid berpendapat sekalipun Luqman adalah orang hitam dari Sudan, namun diberi keistimewaan sari Allah SWT berupa perkataan yng penuh hikmah, orang yang bersahaja, dan juga menjadi hakim bagi kaum Bani Israil. Lihat dalam Ibnu Katsir, Tafsir al-Qur'anal-'Adzim, (Beirut: Dar IbnHazm, 2000), hlm. 1461. Mengenai asal Luqman pun terdapat banyak versi, ada yang mengatakan bahwa Luqman berasal dari Nuba, pendapat lain bahwa Luqman bersal dari Etiopia, dan juga ada berpendapat bahwa Luqman berasal dari Mesir Selatan. Lihat dalam M. QuraishShihab, Tafsir al-Misbah, Vol. 11 (Jakarta: Lentera Hati, 2002), hlm. 125.

${ }^{30}$ Q.S. Luqman (31): 12.

31 as-Sahili menerangkan bahwa anak Luqman yang digambarkan dalam ayat ke 13 bernama Tsaran, sebagaimana yang dikutip oleh Ibnu Katsir. Lihat dalam Ibnu Katsir, Tafsir al-Qur'an ..., hlm. 1462.

${ }^{32}$ Q.S. Luqman (31): 13.
} 
Nasehat Luqman dalam ayat ini dilakukan dari waktu ke waktu, bahwa Luqman menasehati anaknya bukan hanya sekali, namun dilakukan berulangulang kali, karena sifat dasar nasehat adalah sebagi usaha untuik menyadarkan seseorang bukan untuk menghukumi orang, dan juga karena secara gramatical kata (يعظه) merupakan fi 'ilmudhari' yang mengandung arti dilakukan pada masa kini dan yang akan datang. ${ }^{33}$

Kata (بنيّ) merupakan kata yang menggambarkan kemungilan. Kemungilan mengandung arti kasih sayang yang diberikan orang tua kepada anaknya. Orang tua sebagai pendidik anak dalam keluarga, lebih mengedepankan pendekatan kasih sayang dalam mendidik anak. Karena hasil pendidikan yang didapat oleh anak dalam keluarga sebagai refleksi dari pendidikan yang diberikan oleh orang tua. Semakin sayang orang tua kepada anak, maka semakin sayang pula anak kepada orang tua. Jika orang tua sering membentak dan mengancam anak dalam keluarga, maka sikap anak pun akan sama seperti apa yang didapatkannya.

Nasehat Luqman yang berupa larangan berbuat syirik atau menyekutukan Allah SWT adalah menekankan kepada anaknya untuk meninggalkan sesuatu yang buruk sebelum melakukan sesuatu yang baik. Sebagaimana dalam kaidah at-takhliyyahmuqaddamun ala at-tahliyyah (menyingkirkan keburukan lebih utama dari menyangdang perhiasan). ${ }^{34}$

2. Pembina Akhlak

Akhlak merupakan implementasi dari iman yang terdapat dalam hati seseorang. Akhlak lah yang akan menghiasi kehidupan. Jika ayat ke-13 dari Q.S. Luqman adalah penekanan akidah sebagai core dalam kehidupan seorang muslim, maka akhlak adalah pelengkap sekaligus penyempurna dari diri seseorang. Luqman mengajarkan kepada anaknya tentang pentingnya akhlak (budi pekerti) dalam kehidupan seseorang, bahkan dalam zaman melinium sekalipun, akhlak menjadi salah satu tumpuan pendidikan anak. Pendidikan akhlak sebagai penyeimbang dari pendidikan kognisi dan

${ }^{33}$ M. QuraishShihab, Tafsir ..., hlm. 127.

${ }^{34}$ Ibid. 
psikomotor, yang kemudian dalam dunia pendidikan sekarang disebut dengan pendidikan karakter.

Terdapat beberapa pendidikan akhlak yang disimpulkan dalam rangkaian nasehat Luqman kepada anaknya, yaitu: pertama, akhlak kepada orang tua, kedua adalah akhlak kepada orang lain.

a. Setiap anak harus dididik untuk menghormati kedua orang tua, yaitu dengan berbuat baik dan berterima kasih kepada orang tua. Orang tua adalah orang yang pertama mengasuh anak dari kecil hingga dewasa. Orang tua juga yang menjadi orang dewasa yang didapatkan anak dalam lingkungan pertamanya, yaitu keluarga. Maka menjadi ironi, jika kita meminta anak untuk hormat kepada orang lain yang lebih dewasa sementara anak tidak hormat kepada orang tuanya sendiri dalam keluarga. ${ }^{35}$ Allah SWT telah mengingatkan kita tentang bagaimana susah dan payahnya ibu mengandung dan menyusui anak sampai umur dua tahun;

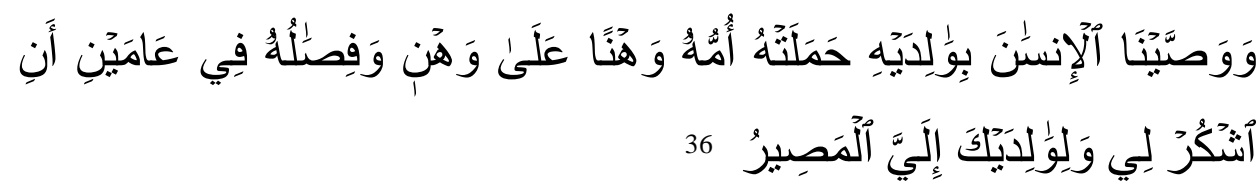

Orang tua diciptakan Allah SWT sebagai pelindung anak, terlebih ibu yang secara kodrati diciptakan untuk mengandung, melahirkan, memberikan nutrisi dan mengasuh anaknya. Orang tua bersedia mengorbankan apa saja untuk anaknya tanpa mengeluh, memberikan semua yang terbaik untuk anak. ${ }^{37}$ Maka sudah sepatutnya anak berbakti kepada orang tua sebagi bentuk rasa hormat dan terima kasih atas semua usaha yang diberikan orang tua kepada anak.

\footnotetext{
${ }^{35}$ Banyak hadis yang menerangkan keutamaan dalam menghormati orang tua, seperti hadis رضي الله في رضى الو الدين و سخط الله في سخط الو الدين Hadis nomor 1899 dalam at-Tirmidzi, Sunan Tirmidzi,(t.t.: Dar Hadarah, 2010), hlm. 387. Ada hadis lain yang menyatakan keutamaan ibu untuk dimuliakan oleh anaknya من أحق الناس بحسن صحابتي: فال أمك, قال ثم من, قال ثم أمك, قال ثم من, قال ثم أمك, قال ثم من, قال ثم أبوك Lihat dalam al- Bukhari, shahihbukhari: nomor hadis 5971, (t.t.: Dar Hadarah, 2010), hlm. 967. ${ }^{36}$ Q.S. Luqman (31): 14.

${ }^{37}$ M. QuraishShihab, Tafsir ..., hlm. 130.
} 


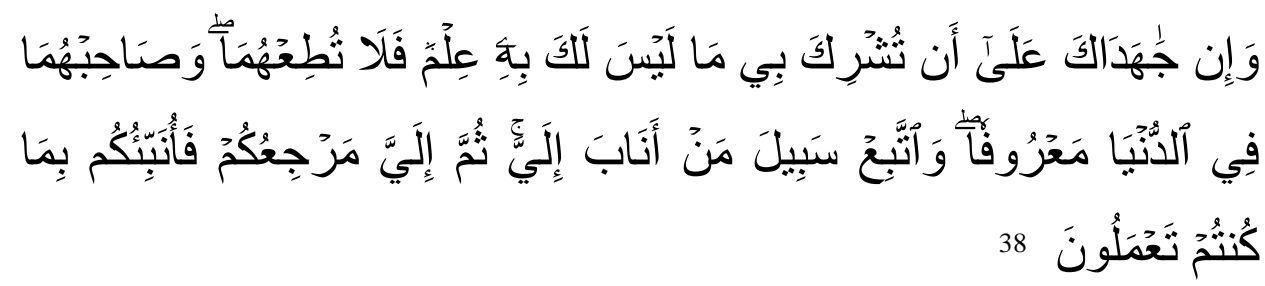

Anak harus hormat dan memperlakukan kedua orang tuanya dengan baik dalam urusan dunia. Untuk urusan akhirat (agama) anak juga harus mengikuti jalan orang tua jika sesuai dengan ajaran yang benar (agama tauhid), namun jika jalan orang tua bertentangan dengan prinsip agama (memalingkan dari menyembah Allah) maka anak tidak perlu mengikuti ajakan orang tua.

Kata (الدنيا) dalam ayat ke-15 mengisyaratkan tiga tugas anak kepada orang tua, pertama, anak harus mempergauli orang tua dengan baik dalam urusan dunia. Kedua, bahwa tugas berbakti kepada orang tua hanya bersifat sementara, yaitu hanya di dunia. Ketiga, bahwa berbaktinya anak kepada orang tua di dunia sebagai bekal untuk kembali kepada Allah SWT. ${ }^{39}$

b. Akhlak terhadap orang lain, adalah memiliki sopan santun dalam berinteraksi dengan sesama manusia. Adab atau sopan santun dalam berinteraksi dengan oran lain dapat dilakukan dengan beberapa cara, antara lain: pertama, bertemu orang lain dengan wajah berseri penuh rendah hati bukan dengan memalingkan wajah sebagai bentuk kesombongan dan penghinaan kepada orang lain. Kedua adalah berjalan dengan penuh rasa tawadhu' dan sewajarnya (tidak membusungkan dada, tidak merundukkan kepala, tidak berlari, dan juga tidak terlalu lambat). Ketiga adalah menjaga suara, agar tidak bersuara yang kencang sehingga menggangu orang yang mendengarkan namun juga tidak terlalu pelan seperti orang berbisik. ${ }^{40}$

Seperti nasehat Luqman dalam ayat 18-19:

\footnotetext{
${ }^{38}$ Q.S. Luqman (31): 15.

${ }^{39}$ M. QuraishShihab, Tafsir ..., hlm. 133.

${ }^{40}$ Ibid., hlm. 138-139
} 


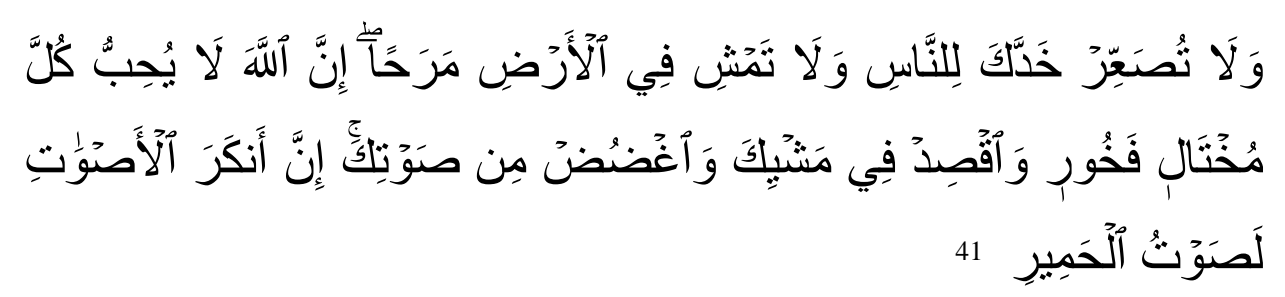

3. Pembinaa Ibadah dan Agama

Pembinaan beribadah pada anak dimulai dari dalam keluarga. Pembinaan ibadah bagi anak yang masih kecil adalah yang mengandung gerak, sedangkan pengertian tentang ajaran agama belum dapat dipahami oleh anak. Karena itu, ajaran agama yang abstrak tidak menarik perhatiaananak, anak bisa melakukan shalat, meniru orang tuanya, kendatipun ia tidak mengerti apa yang dilakukan itu.

Luqman mendidik anaknya dengan perintah shalat, mengerjakan amal shaleh berupa mengajak kepada hal ma'ruf dan mencegah dari perbuatan munkar, juga menasehati untuk membentengi diri dari kegagalan yaitu dengan menumbuhkan rasa sabar dan tabah dalam hati. ${ }^{42}$

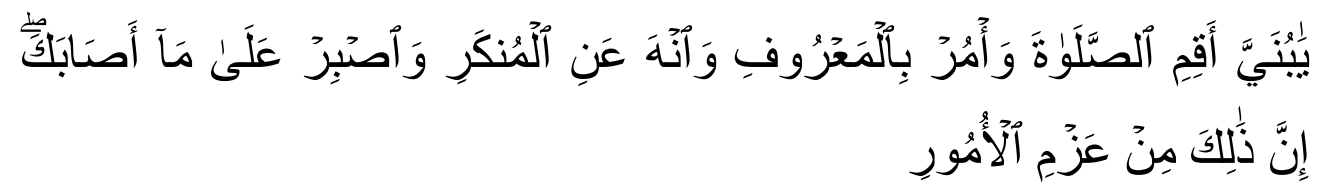

Memerintahkan anak untuk mengerjakan ibadah dan melaksanakan amal kebajikan adalah dengan cara persuasif, ${ }^{43}$ mengajak dan membimbing anak dengan kelembutan sekalipun tujuannya adalah untuk tetap konsisten menjalankan ibadah dan beramal saleh.Amar ma'ruf mengandung arti bahwa anak dibiasakan untuk mengajak orang lain berbuat kebajikan dengan tidak lupa untuk memulai dengan mengerjakan kebajikan tersebut. Sedang nahi munkar berarti anak dididik untuk mencegah orang lain berbuat mungkar dengan diawali oleh dari diri anak sendiri untuk membenci dan menjauhi perbuatan munkar yang dibenci oleh Allah SWT. Orang tua juga mengajarkan

${ }^{41}$ Q.S. Luqman (31): 18-19.

${ }^{42}$ Ibid., hlm. 138-139

${ }^{43}$ Luqman mengawali perintah shalat kepada anaknya dengan kata sapaan sayang (بني), mengisyaratkan bahwa orang tua harus menggunakan kasih sayang dalam mendidik anak, meskipun dalam menegakkan kedisplinan seperti ibadah shalat. Lihat Ibid., hlm. 136. 
kepada untuk mampu menahan diri, mempunyai keteguhan hati, dan tekad yang kuat dalm menjalankan perintah Allah berupa ibadah dan amal saleh. ${ }^{44}$

4. Pembinaa kepribadian dan sosial anak

Kepribadian terbentuk melalui semua pengalaman dan nilai-nilai yang diserap anak dalam setiap masa pertumbuhan dan perkembangannya. Apabila nilai-nilai agama banyak masuk ke dalam pribadi seseorang, maka tingkah laku orang tersebut akan banyak diarahkan dan dikendalikan oleh nilai-nilai agama.

Memperhatikan cara Luqman mendidik anak tentang kesadaran akan pengawasan Allah terhadap semua manusia dan makhluk-Nya, baik yang terlihat, maupun yang tersembunyi di mana pun, di langit maupun di darat. Seperti yang diungkap dalam al-Qur'an;

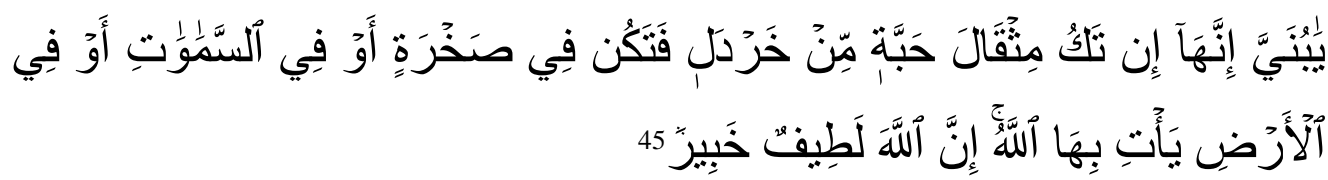

Menanamkan kesadaran dan pengawasan dari Allah pribadi anak akan menumbuhkan pengendalian kuat dalam diri anak. Ditambah dengan mengajak orang untuk berbuat baik dan menjauhi yang mungkar, serta sifat sabar dalam menghadapi berbagai musibah dan keadaan. Selanjutnya kepribadian tersebut hendaknya dihiasi pula dengan sifat-sifat yang menyenangkan yaitu ramah, rendah hati, dan suara yang lemah-lembut. ${ }^{46}$ Maka keutuhan pribadi muslim yang dinasihatkan oleh Luqman adalah pribadi beriman, taat beribadah, teguh pendirian, pandai bergaul, ramah dan mempunyai kepedulian terhadap masyarakat.

Ulwan mengatakan bahwa kewajiban bagi pendidik untuk menanamkan dasar-dasar kejiwaan (aqidah iman dan taqwa, persaudaraan dan percintaan, kasih sayang, altruisme, sabar, sikap berani tampil dan berani jika benar) pada anak sejak kecil, maka anak akan terhindar dari hidup yang

${ }^{44}$ Al-Qahthani, TarbiyatulAuladfiDho'i Kitab waSunnah, (Jami'aHuquq Mahfudhoh, 2011), hlm. 27.

${ }^{45}$ Q.S. Luqman (31): 16.

${ }^{46}$ Lihat Q.S. Luqman (31): 17-19. 


\section{| ADRIAN, IRFAN | Peran Orang Tua sebagai Pendidik Anak}

menyimpang di tengah-tengah masyarakat. Karena bila anak dibiarkan tanpa perhatiandan penanaman dasar kejiwaan dalam diri mereka, dikhawatirkan mereka akan menyimpang, menjadi alat penghancur tata nilai dan menjadi benih-benih kriminalitas sosial. ${ }^{47}$

Ulwan juga membatasi hak-hak sosial yang penting dan harus diajarkan kepada anak-anak kita, ke dalam 5 (lima) hak, yaitu hak orang tua, hak keluarga dan nasab, hak guru, hak teman, dan hak orang yang lebih tua. Apabila kelima hak ini ditanamkan dalam pendidikan social anak, diharapkan akan menumbuhkan masyarakat yang saling menolong, produktif, keterikatan yang kuat, mempunyai akhlak yang luhur, serta saling mencintai dan mengkoreksi secara konstruktif. ${ }^{48}$

\section{F. KESIMPULAN}

Uraian di atas memberikan gambaran tentang peran orang tua sebagai pendidikanak dalam keluarga. Keluarga adalah wadah pertama dan utama bagi pendidikan anak. Keluarga sebagai lingkungan pendidikan yang sangat berpengaruh dalam membentuk pola kepribadian anak. Anak mempelajari nilainilai keyakinan (agama), akhlak budi pekerti, komunikasi dan intertaksi sosial, serta ketrampilan hidup dari keluarga dan orang tua. Orang tua bertanggung jawab melaksanakan tugas memelihara, mengasuh, dan mendidik anak lahir dan batin sampai anak menjadi dewasa. Orang tua harus menyadari akan peran penting sebagai pendidik anak yang pertama dan utama dalam keluarga. Usaha dan tekad yang kuat dari setiap orang tua mejadidsar untuk mewujudkan tujuan pendidikan anak dalam keluarga.

Orang tua bisa mencontoh profil Luqman al-Hakim sebagai orang tua yang aware kepada pendidikan anaknya, yaitu dengan menjadi orang tua yang menjadi tauladan bagi anak-anaknya, kemudian mendidik anak mulai dari aspek keimanan,

\footnotetext{
${ }^{47}$ Abdullah Nashih Ulwan, Pendidikan Sosial Anak, terj. Khalilullah Ahmas Maskur H. (Bandung: Remaja Rosdakarya, 1996), hlm. 32.

${ }^{48}$ Ibid.
} 
| ADRIAN, IRFAN | Peran Orang Tua sebagai Pendidik Anak

akhlak dan sopan santun, ibadah dan amal saleh, serta menumbuhkan sikap dan tekad yang kuat dalam berbuat kebajikan dalam diri anak.

\section{DAFTAR PUSTAKA}

Abdullah Nashih Ulwan, Pendidikan Sosial Anak, terj. Khalilullah Ahmas Maskur H. Bandung: Remaja Rosdakarya, 1996.

Berns,Roberta M. Child, Family, School, Community: SocializationandSupport,Stamfort: CengageLearning, 2016.

Al-Bukhari, shahihbukhari: nomor hadis 5971, t.t.: Dar Hadarah, 2015.

Daradjat,Zakiyah.Pendidikan Islam dalam Keluarga dan Sekolah, Bandung: Remaja Rosdakarya, 1994.

Helmawati, Pendidikan Keluarga: Teoritis dan Praktis, Bandung: Remaja Rosdakarya, 2104.

https://en.wiktionary.org/wiki/stem_family.

https://www.britannica.com/topic/joint-family.

Katsir,Ibnu.Tafsir al-Qur'anal- 'Adzim, Beirut: Dar IbnHazm, 2000.

Mahmud, dkk., Pendidikan Agama Islam dalam Keluraga: Sebuah Panduan Lengkap bagi Guru, Orang Tua, dan Calon, Jakarta: Akademia, 2013.

Masturin, "Pendidikan Karakter pada Materi PAI dalam Pembentukan Manusia Berkualitas", Jurnal Pendidikan Dasar Islam Al-Bidayah, Vol. 7 Nomor 1, Tahun 2015 .

O'neil, William F. Ideologi-idelogi Pendidikan. terj. Omi Intan Naomi, Yogyakarta: Pustaka Pelajar, 2001.

Poerbakawatja, Soegarda. dkk., Ensiklopedi Pendidikan, Jakarta: Gunung Jati, 1981. 
| ADRIAN, IRFAN | Peran Orang Tua sebagai Pendidik Anak

Pringgodigdo, A.G. dkk. Ensiklopedi Umum, Jakarta: Yayasan Dana Buku Franklin, 1973.

Al-Qahthani, TarbiyatulAuladfiDho'i Kitab waSunnah, Jami'aHuquq Mahfudhoh, 2011.

Shihab,M. Quraish.Tafsir al-Misbah, Vol. 11, Jakarta: Lentera Hati, 2002.

Tafsir, Ahmad.Ilmu Pendidikan dalam Perspektif Islam, Bandung: Remaja Rosdakarya, 1991.

Taubah,Mufatihatut. "Pendidikan Anak dan Keluarga Perspektif Islam". Jurnal Pendidikan Agama Islam, Vol. 03, No. 1 Mei 2015.

At-Tirmidzi, Sunan Tirmidzi,t.t.: Dar Hadarah, 2015. 